\title{
Early Cretaceous denudation related to convergent tectonics in the Baikal region, SE Siberia
}

\author{
P.A. VAN DER BEEK ${ }^{1,2}$, D. DELVAUX ${ }^{3}$, P.A.M. ANDRIESSEN ${ }^{1} \&$ K.G. LEVI ${ }^{4}$ \\ ${ }^{\prime}$ Faculty of Earth Sciences, Vrije Universiteit Amsterdam, Netherlands \\ ${ }^{2}$ Present address: Research School of Earth Sciences, Australian National University, Canberra ACT 0200, \\ Australia \\ ${ }^{3}$ Department of Geology and Mineralogy, Royal Museum for Central Africa, Tervuren, Belgium \\ ${ }^{4}$ Institute of the Earth's Crust, Siberian Academy of Sciences, Irkutsk, Russia
}

\begin{abstract}
We present 24 new apatite fission track (AFT) ages and 18 track length measurements from the Baikal region, SE Siberia. Most samples have AFT ages between 140 and $100 \mathrm{Ma}$, with relatively high mean track lengths $(c .13 .2 \mu \mathrm{m})$. The relationship between AFT ages, elevation and mean track lengths indicate that the samples record rapid cooling during the Early Cretaceous (140-120 Ma), as also shown by thermal history inversion of track length distributions. Cooling took place during a Late Jurassic-Early Cretaceous orogenic phase, related to closure of the Mongol-Okhotsk ocean and reflected in the exhumation of metamorphic core complexes followed by thrusting and reverse faulting, basin inversion and large vertical motions. The variation in AFT ages throughout the study area can be partly explained by differences in geothermal structure but differential denudation also played a role. Minimum amounts of Early Cretaceous denudation are estimated at $2-3 \mathrm{~km}$.
\end{abstract}

Keywords: Mesozoic, Baikal region, fission track dating, denudation.

The Baikal rift in southeastern Siberia has become one of the type examples for continental rifting. The evolution of the rift is strongly influenced by the pre-existing tectonic fabric, which developed during a protracted history of pre-rift orogenic evolution (eg., Logatchev \& Zorin 1992). Therefore, an understanding of the pre-rift geodynamic evolution of the Baikal region is essential to understand the Cenozoic evolution of the rift zone.

The Baikal rift developed at the southern margin of the Siberian platform, along the suture with the Central Asian fold belt (Fig. 1). The pre-rift tectonic history of the area is linked to the opening and closure of the Palaeo-Asian and Mongol-Okhotsk oceans, during Late Proterozoic to Mesozoic times (e.g., Zonenshain et al. 1990). A Late Palaeozoic-Early Mesozoic phase of continental break-up, followed by Mesozoic convergence, is recognized throughout central Asia (cf. Allen et al. 1991; Ermikov 1994; Parfenov et al. 1995). The importance of Mesozoic deformation in the area has been realised for some time but the associated vertical motions have not been quantified before.

During recent years, apatite fission track thermochronology has been established as an efficient technique to study intra-plate vertical motions that were accompanied by regional denudation (e.g., Foster \& Gleadow 1992; Brown et al. 1994; Hendrix et al. 1994). In this paper, we present apatite fission track data that record an important Early Cretaceous phase of cooling and denudation in the Baikal region. We interpret these data within the framework of the tectonic evolution of Central Asia and discuss the relevance towards understanding the morphotectonics of the Baikal rift zone.

\section{Late Proterozoic-Mesozoic evolution of the Baikal region}

The Baikal rift is bordered to the northwest by the Archaean-Early Proterozoic Siberian craton, which is covered by Late Proterozoic, Palaeozoic and Mesozoic platform sediments. To the southeast, the basement consists of the poly-stage Sayan-Baikal fold belt (Figs $1 \& 2$ ). The Sayan-Baikal fold belt originated from Silurian-Devonian closure of the Palaeo-Asian ocean and collision of several 'Trans-baikalian' micro-continents with the Siberian craton to the north (Berzin \& Dobretsov 1994; Melnikov et al. 1994). A significant proportion of the belt is composed of Devonian late/post orogenic granitic plutons.

Late Palaeozoic-Early Mesozoic extension along the southern border of the Siberian craton is recorded by basin formation and magmatism (Allen et al. 1991; Ermikov 1994) and marks the opening of the Mongol-Okhotsk ocean. From Late Permian to Late Jurassic times the southern border of the Siberian craton developed in an active margin setting, until collision of the Siberian and Northern Chinese cratons took place in the Early Cretaceous (Zonenshain et al. 1990; Scotese \& Golonka 1992; Enkin et al. 1992). To the south east of Lake Baikal, an en-echelon chain of narrow extensional basins developed during the Late Triassic, which are filled by Triassic-Jurassic volcanics and continental/ limnic sediments (Fig. 2). Late Jurassic-Early Cretaceous mega-breccias and conglomerates unconformably overlie the earlier basin fill and are related to basin inversion (Ermikov 1994). The basement highs between these basins have been interpreted as metamorphic core complexes which were regarded to have developed during Late Palaeozoic 


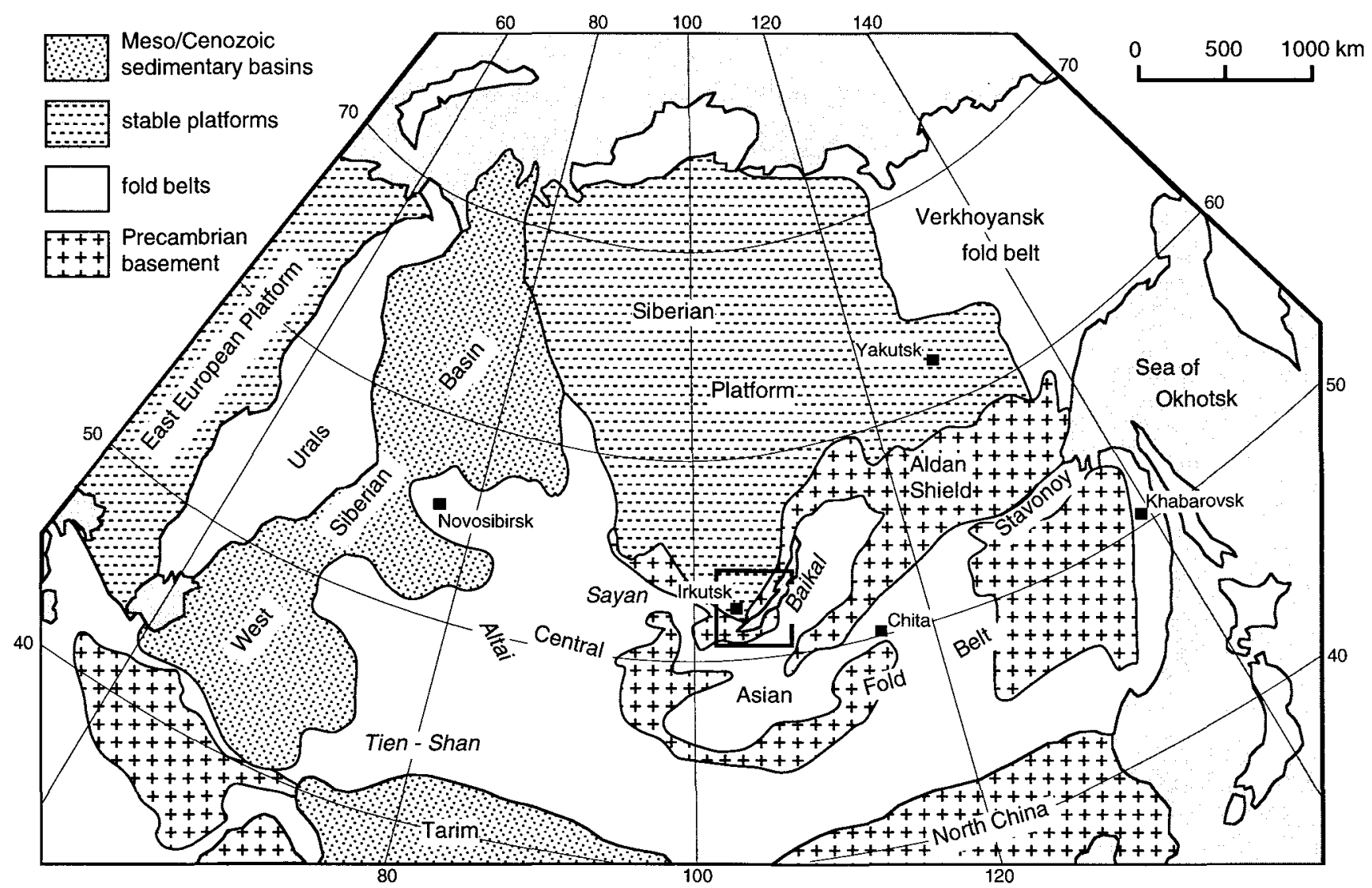

Fig. 1. Generalized tectonic map of Siberia and adjacent regions. Modified and simplified from Zonenshain et al. (1990). Inset shows extent of study area (Fig. 2).

extension (e.g., Melnikov et al. 1994). New K-Ar data, however, suggest Early Cretaceous (113-100 Ma) ages for the final exhumation of these massifs (Sklyarov et al. 1994).

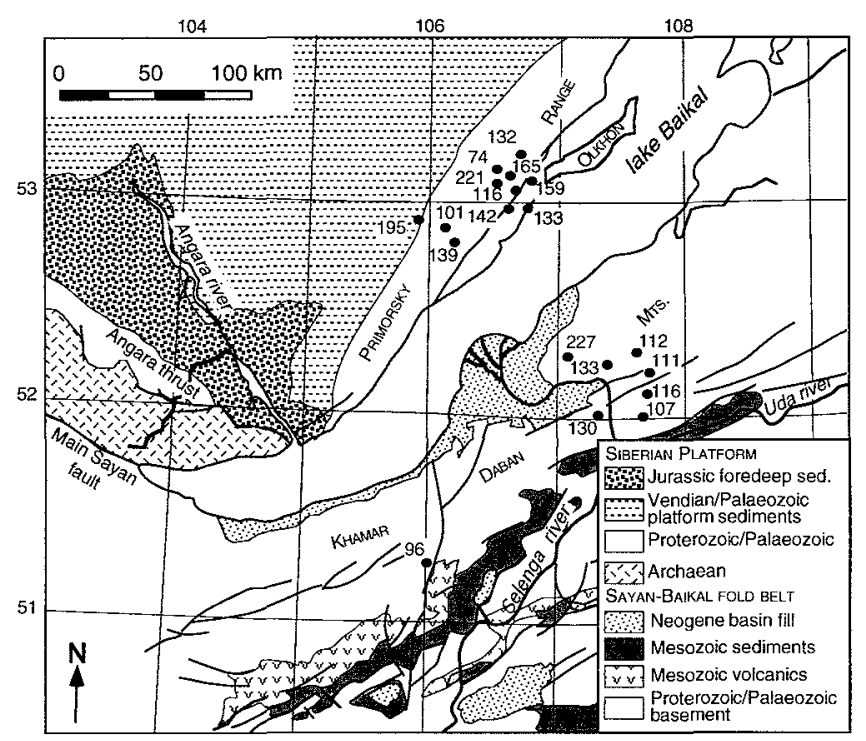

Fig. 2. Simplified tectonic map of southern and central Baikal, with emphasis on Mesozoic structures. Apatite fission track samples are indicated by their ages; to avoid clutter not all samples from the Priolkhon area have been plotted. Modified from Delvaux et al. (1995).
Trachy-basaltic volcanics and dykes have radiometric ages as young as 127-100 Ma (Ermikov 1994). Thus, closure of the Mongol-Okhotsk ocean seems to have been accompanied by a complex Cordilleran-type interplay of extensional and compressional phases within the Trans-Baikal fold belt. A late Early Cretaceous phase of $\mathrm{N}-\mathrm{S}$ compression has, however, been clearly demonstrated from microstructural analyses in and around the inverted basins (Delvaux et al. 1995); its age is constrained by structural and stratigraphic relationships with the volcano-sedimentary succession. Compressional deformation affected a wide area, including the fold belt as well as the Siberian Platform (Ermikov 1994; Delvaux et al. 1995). To the west of Lake Baikal, Mesozoic vertical motions are recorded by the Jurassic West Baikal foredeep, which developed along the southern margin of the Siberian Platform (Fig. 2). This (foreland ?) basin was overthrust by Archaean basement along the Angara thrust during the Cretaceous.

During a period of tectonic quiescence in the Late Cretaceous-Palaeogene, the pre-existing orogen was peneplained in a warm and humid climate, causing the formation of kaolinite-laterite palaeosols (Mats 1993; Kashik \& Mazilov 1994). Cenozoic rifting was underway by the mid-Oligocene (Logatchev 1993; Mats 1993). The preservation of pre-rift weathering remnants suggests that subsequent erosion was minimal (Mats 1993). The Baikal rift developed as a series of asymmetric half-graben, with the border-zone of the Siberian craton (PrimorskyObruchevsky faults) acting as the main border fault system (Fig. 2). To the southeast, the basement gradually 

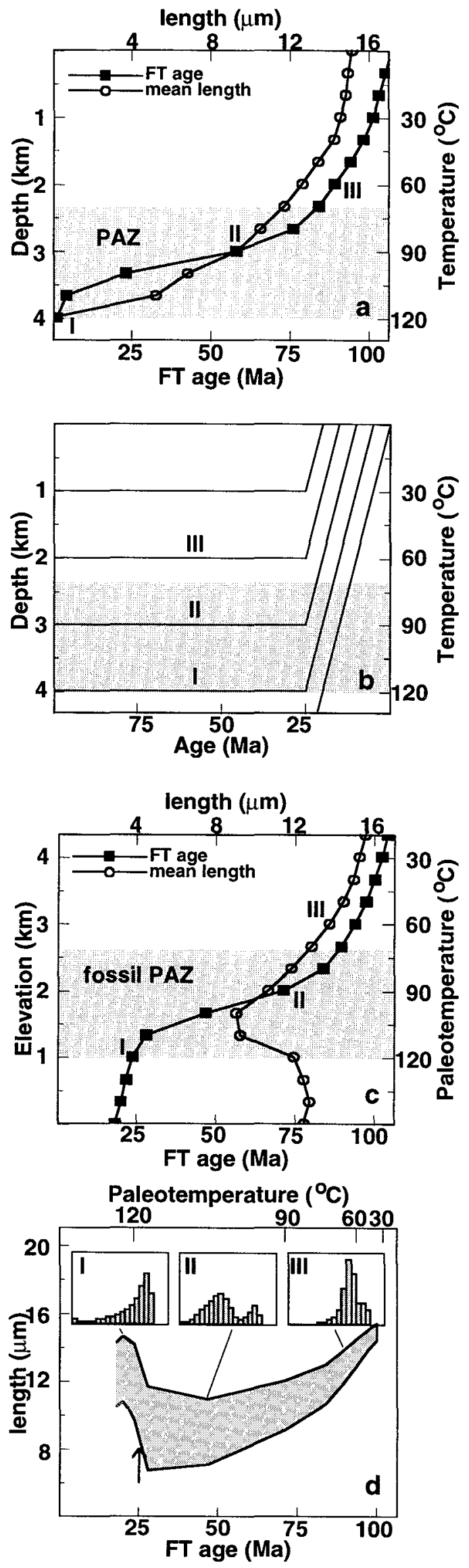

rises; the Khamar Daban range, which forms the eastern flank of the rift, is not cut by border faults. The Primorsky and Obruchevski faults enclose the Olkhon block, which can be regarded as a very large tilted fault block (Mats 1993). Two main stages are recognized within the evolution of the rift (Logatchev 1993; Mats 1993): an older (Oligocene-mid Pliocene) phase of slow rifting, low relief and low-energy sedimentation and a younger (mid-Pliocene-Recent) phase of rapid basin deepening, major relief generation and coarse clastic sedimentation.

\section{Apatite fission track thermochronology}

Over the past decade, apatite fission track (AFT) thermochronology has become a well established and widely used technique to constrain the low temperature $\left(<120^{\circ} \mathrm{C}\right)$ thermal histories of rocks (cf. Brown et al. 1994 for a review). Under tectonically stable conditions, AFT ages and mean track lengths will decrease systematically with increasing temperature (and hence depth) as a result of progressive annealing of fission tracks (Fig. 3a). The main control on the pattern of AFT ages and track lengths is exerted by the geothermal gradient; secondary controls are exerted by the duration of tectonically stable conditions and the chemical composition of the apatites (Green et al. $1989 a$ ). At temperatures between c. 70 and $120^{\circ} \mathrm{C}$, in the partial annealing zone (Wagner 1979), the amount of annealing increases rapidly towards total.

When a tectonic block cools as a result of exhumation, remnants of the characteristic AFT age/depth pattern may be retained, producing a trend of increasing AFT ages with elevation (Fig. 3b \& c). The base of the fossil (exhumed) partial annealing zone, when exposed, will produce a characteristic break in slope in the age/elevation plot, the age of which approximates the initiation of cooling/exhumation (Gleadow \& Fitzgerald 1987). Samples from below the break in slope were exhumed from temperatures $\geq 120^{\circ} \mathrm{C}$, and contain only tracks formed during and after cooling. In contrast, samples above the break in slope contain two generations of tracks, one from before and one from after the onset of cooling. The actual shape of the age/elevation plot, and the trend of track length distributions with elevation, will depend on the amount and rate of exhumation (Brown et al. 1994).

Fig. 3. (a) Variation of fission track age and mean track length with temperature, calculated using the annealing model of Laslett $e t$ al. (1987), for a $100 \mathrm{Ma}$ stable thermal regime. A depth scale is added assuming a $30^{\circ} \mathrm{C} \mathrm{km}^{-1}$ geotherm. Both fission track age and mean track length decrease rapidly between $c .70$ and $120^{\circ} \mathrm{C}$ in the partial annealing zone (PAZ). (b) Exhumation paths of rocks from different structural levels for a history of $5 \mathrm{~km}$ of exhumation from $25 \mathrm{Ma}$ onwards; labels I, II and III indicate rocks exhumed from below, within and above the PAZ (shaded) and are also indicated in the other plots. (c) Resulting pattern of fission track ages and mean track lengths, the base of the fossil PAZ is characterized by a break in slope in the age/elevation plot and records the amount of exhumation as well as the timing of its onset. (d) Resulting age/length plot; shaded area represents mean length \pm standard deviation for samples from different palaeotemperatures (scale on top). Samples from the base of the fossil PAZ produce the low-age peak in the diagram and date the onset of exhumation. Insets show modelled fission track length distributions for 'samples' I, II and III. 
The dependence of observed track length distributions (Gleadow et al. 1986) on thermal history can also be used to constrain the amount and timing of exhumation. A plot of fission track age against mean track length of an area that has undergone cooling will show a characteristic 'boomerang' shape (Fig. 3d); the length peak at young ages corresponds to samples which were exhumed from the base of the partial annealing zone, and thus retain only tracks formed after the onset of cooling (e.g., Omar et al. 1989). The kinetics of annealing in apatite are now becoming understood in a quantitative manner (Laslett et al. 1987; Green et al. 1989b; Lutz \& Omar 1991). As a result, AFT thermochronology is presently able to record not only the amount and timing of cooling of a sample, but also to reconstruct its cooling trajectory $\left(T-t\right.$ path) below $120^{\circ} \mathrm{C}$.

It should be noted that fission track thermochronology strictly records cooling of a sample only. Where fission track data show the characteristic relationship to elevation described above, or when additional geological data are available (e.g., absence of contemporaneous magmatic or geothermal activity, correspondence of cooling intervals with periods of sediment deposition in nearby sedimentary basins, presence of planation surfaces of corresponding age), cooling can be interpreted to result from exhumation. The amount of exhumation can be quantified if the geothermal gradient is known; in most cases, cooling from $120^{\circ} \mathrm{C}$ represents $3.5 \pm 1 \mathrm{~km}$ of exhumation.

\section{Denudation history of the Baikal region from fission track thermochronology}

\section{Sampling and procedures}

Samples for fission track analysis were collected from the marginal mountains flanking both sides of the present-day rift (cf. Fig. 2). A list of sample locations and lithologies is given in Table 1. To the NW of the rift, an age/elevation profile was collected in the Primorsky range, as well as a profile across it. A number of samples were taken from the Olkhon block in the Priolkhon region. Samples from the NW of the rift comprise mainly high-grade Proterozoic basement rocks. One sample (BAI 16) was taken from the basal (Vendian) unit of the Siberian platform succession. To the SE of the rift, samples were collected in the Khamar Daban range, both north and south of the Selenga river valley. Here, all samples were Palaeozoic plutonic and metamorphic rocks. Sample preparation and processing techniques are outlined by van der Beek (1995) and follow the criteria defined by Hurford \& Green (1983) and Hurford (1990).

\section{Results}

Apatite fission track (AFT) age and mean track length data are summarised in Table 2 . All ages are reported as central ages (Galbraith \& Laslett 1993) with $\pm 1 \sigma$ errors. They show a relatively large spread, varying between $57 \pm 10$ and $227 \pm 19 \mathrm{Ma}$. Ages significantly younger than $100 \mathrm{Ma}$ were, however, only encountered in samples from the Primorsky

Table 1. Sample details

\begin{tabular}{|c|c|c|c|c|c|c|}
\hline Sample & $\begin{array}{c}\text { VUA } \\
\text { lab. no. }\end{array}$ & Location & Latitude & Longitude & $\begin{array}{c}\text { Elev. } \\
(\mathrm{m})\end{array}$ & Lithology \\
\hline BA058 & 1184 & Sarminski Gonets & N53:02:44 & E106:42:23 & 1040 & Mylonitic gneiss \\
\hline BA060 & 1182 & Sarminski Gonets & N53:03:17 & E106:42:00 & 1180 & Sheared granite \\
\hline BA061 & 1183 & Sarminski Gonets & N53:03:55 & E106:39:51 & 1330 & Sheared granite \\
\hline BAI 1 & 1154 & Sarma river mouth & N53:07:44 & E106:50:00 & 500 & Mylonitic qz-fsp gneiss \\
\hline BAI 2 & 1155 & Sarma river mouth & N53:08:00 & E106:50:41 & 720 & Mylonitic qz-fsp gneiss \\
\hline BAI 3 & 1156 & Sarma river mouth & N53:08:00 & E106:50:55 & 960 & $\mathrm{Qz}-\mathrm{fsp}-$ bi gneiss \\
\hline BAI 4 & 1157 & Sarma river mouth & N53:08:32 & E106:50:55 & 1050 & Felsic gneiss \\
\hline BAI 5 & 1158 & Sarma river mouth & N53:08:32 & E106:50:14 & 820 & Qz-fsp-bi gneiss \\
\hline BAI 6 & 1159 & Muchar bay & N53:01:52 & E106:45:14 & 455 & Amphibolite \\
\hline BAI 7 & 1160 & '989 peak' & $\mathrm{N} 52: 57: 41$ & E106:48:52 & 990 & Metagabbro \\
\hline BAI 8 & 1161 & '989 peak' & N52:58:56 & E106:48:25 & 830 & Gt bearing $q \mathrm{z}-\mathrm{fsp}-\mathrm{bi}$ gneiss \\
\hline BAI 9 & 1162 & '989 peak' & N52:59:36 & E106:47:03 & 625 & Amphibolite \\
\hline BAI 10 & 1163 & Olkhon gate & N53:00:48 & E106:54:33 & 455 & Qz-fsp-bi gneiss \\
\hline BAI 11 & 1164 & '989 peak' & $\mathrm{N} 52: 56: 32$ & E106:47:57 & 455 & Chl bearing quartzite \\
\hline BAI 14 & 1165 & Tyrdan quarry & N52:44:36 & E106:19:15 & 675 & Metagabbro \\
\hline BAI 15 & 1166 & Kyret river & N52:48:16 & E106:15:00 & 730 & Schistose rapakivi granite \\
\hline BAI 16 & 1167 & Kodja Stej village & N52:50:56 & E106:03:58 & 730 & Vendian sandstone \\
\hline BAI 17 & 1168 & Barguzin road & N51:56:14 & E107:41:53 & 1020 & Granite \\
\hline BAI 18 & 1169 & Barguzin road & N51:58:39 & E107:42:04 & 1200 & $\mathrm{Bi}$-fsp bearing meta-arkose \\
\hline BAI 19 & 1170 & '1349 peak' & N52:01:05 & E107:44:04 & 1300 & Granite \\
\hline BAI 20 & 1171 & Irkilik valley & N52:07:00 & E107:45:23 & 700 & Diorite \\
\hline BAI 21 & 1172 & Ostrog village & N52:09:57 & E107:26:37 & 500 & Leucocratic migmatite \\
\hline BAI 22 & 1173 & road to Chergino & N52:12:23 & E107:09:10 & 700 & Metagabbro \\
\hline BAI 27 & 1176 & '1510 peak' & N51:23:02 & E106:01:07 & 1250 & Quartzite \\
\hline BAI 30 & 1179 & Sarmen Edzje mnt & N51:16:41 & E.106:10:19 & 1030 & Metadacite \\
\hline BAI 32 & 1180 & Otsjurkovo quarry & N51:56:30 & E107:26:42 & 640 & Ap bearing diorite \\
\hline
\end{tabular}


Table 2 Apatite fission track analytical data

\begin{tabular}{|c|c|c|c|c|c|c|c|c|c|c|c|}
\hline Sample & $\begin{array}{l}\text { Elev. } \\
(\mathrm{m})\end{array}$ & $\begin{array}{l}\text { No. } \\
\text { grains }\end{array}$ & $\begin{array}{c}\rho_{\mathrm{s}} N_{\mathrm{s}} \\
\left(\times 10^{6} \mathrm{~cm}^{-2}\right)\end{array}$ & $\begin{array}{c}\rho_{\mathrm{i}}\left(N_{\mathrm{i}}\right) \\
\left(\times 10^{\mathrm{h}} \mathrm{cm}^{-2}\right)\end{array}$ & $\begin{array}{c}\rho_{\mathrm{d}}\left(N_{\mathrm{d}}\right) \\
\left(\times 10^{6} \mathrm{~cm}^{-2}\right)\end{array}$ & $\begin{array}{l}P\left(\chi^{2}\right) \\
(\%)\end{array}$ & $\begin{array}{l}\text { Age } \pm 1 \sigma \\
\text { (Ma) }\end{array}$ & $\begin{array}{c}D \\
(\%)\end{array}$ & $\begin{array}{l}\text { Mean length } \\
\quad(\mu \mathrm{m})\end{array}$ & $\begin{array}{l}\text { St. dev. } \\
(\mu m)\end{array}$ & $\begin{array}{l}\text { No. of } \\
\text { tracks }\end{array}$ \\
\hline \multicolumn{12}{|c|}{ Primorsky range (W of Lake Baikal) } \\
\hline BA058 & 1040 & 18 & $0.193(228)$ & $0.632(374)$ & $0.025(3111)$ & 75 & $87 \pm 9$ & 12 & & & \\
\hline BA060 & 1180 & 13 & $0.654 \quad(58)$ & $0.327(145)$ & $0.025(3111)$ & 75 & $57 \pm 10$ & 9 & & & \\
\hline BA061 & 1330 & & & & & & & & $12.8 \pm 0.2$ & 1.1 & 36 \\
\hline BAI 1 & 500 & 16 & $0.455(292)$ & $0.838(269)$ & $2.690(3314)$ & 25 & $159 \pm 17$ & 14 & $12.0 \pm 0.2$ & 1.2 & 40 \\
\hline BAI 2 & 720 & 20 & $1.035(668)$ & $1.791(578)$ & $0.025(3111)$ & 25 & $165 \pm 14$ & 13 & $12.3 \pm 0.2$ & 1.3 & 65 \\
\hline BAI 3 & 960 & 19 & $0.204(212)$ & $0.505(262)$ & $2.690(3314)$ & $\ll 1$ & $132 \pm 22$ & 57 & & & \\
\hline BAI 4 & 1050 & 20 & $0.067 \quad(85)$ & $0.295(187)$ & $2.690(3314)$ & 2.5 & $74 \pm 12$ & 30 & & & \\
\hline BAI 5 & 820 & 20 & $0.130(145)$ & $0.166 \quad(92)$ & $0.025(3111)$ & 99 & $221 \pm 32$ & 10 & & & \\
\hline BAI14 & 675 & 20 & $1.018(862)$ & $2.189(927)$ & $2.690(3314)$ & 2.5 & $139 \pm 10$ & 15 & $13.4 \pm 0.1$ & 1.0 & 100 \\
\hline BAI15 & 730 & 20 & $0.330(299)$ & $0.921(417)$ & $0.025(3111)$ & 25 & $101 \pm 10$ & 12 & & & \\
\hline BAI16 & 730 & 20 & $0.823(654)$ & $1.258(500)$ & $2.690(3314)$ & 10 & $195 \pm 16$ & 15 & $12.6 \pm 0.1$ & 1.3 & 102 \\
\hline \multicolumn{12}{|c|}{ Priolkhon area/Olkhon block (W. of Lake Baikal) } \\
\hline BAI 6 & 455 & 18 & $1.245(719)$ & $3.227(932)$ & $2.690(3314)$ & 50 & $116 \pm 9$ & 11 & $13.7 \pm 0.1$ & 1.0 & 100 \\
\hline BAI 7 & 990 & 15 & $1.877(1162)$ & $4.248(1315)$ & $2.690(3314)$ & 50 & $132 \pm 9$ & 10 & $13.6 \pm 0.1$ & 1.1 & 102 \\
\hline BAI 8 & 830 & 16 & $1.547(1144)$ & $3.065(1133)$ & $0.025(3111)$ & 10 & $142 \pm 11$ & 13 & $13.6 \pm 0.1$ & 1.1 & 100 \\
\hline BAI 9 & 625 & 17 & $0.670(412)$ & $1.634(502)$ & $2.690(3314)$ & $\ll 1$ & $130 \pm 14$ & 30 & $13.7 \pm 0.1$ & 1.1 & 100 \\
\hline BAI10 & 455 & 20 & $1.642(1335)$ & $3.910(1590)$ & $0.025(3111)$ & 25 & $120 \pm 9$ & 11 & $13.3 \pm 0.1$ & 0.9 & 100 \\
\hline BAI11 & 455 & 19 & $0.970(490)$ & $2.110(533)$ & $2.690(3314)$ & 2.5 & $133 \pm 14$ & 24 & & & \\
\hline \multicolumn{12}{|c|}{ Khamar Daban mountains ( $E$ of Lake Baikal) } \\
\hline BAI17 & 1020 & 20 & 2.954(1911) & $8.252(2669)$ & $2.690(3314)$ & 1 & $107 \pm 6$ & 14 & $13.1 \pm 0.1$ & 1.1 & 101 \\
\hline BAI18 & 1200 & 20 & $1.578(858)$ & $4.069(1106)$ & $2.690(3314)$ & $\ll 1$ & $116 \pm 9$ & 22 & $13.4 \pm 0.1$ & 1.1 & 100 \\
\hline BAI19 & 1300 & 20 & $0.909(739)$ & $2.504(1018)$ & $2.690(3314)$ & 75 & $111 \pm 8$ & 9 & $13.3 \pm 0.1$ & 1.0 & 100 \\
\hline BAI20 & 700 & 20 & $2.378(1073)$ & $6.502(1467)$ & $2.690(3314)$ & 75 & $112 \pm 7$ & 9 & $12.6 \pm 0.1$ & 0.9 & 70 \\
\hline BAI21 & 500 & 18 & $0.772(897)$ & $1.727(1003)$ & $2.690(3314)$ & 25 & $133 \pm 9$ & 12 & & & \\
\hline BAI22 & 700 & 20 & $1.155(578)$ & $1.526(382)$ & $2.690(3314)$ & 10 & $227 \pm 19$ & 15 & $13.8 \pm 0.1$ & 1.0 & 100 \\
\hline BAI27 & 1250 & 15 & $0.653(410)$ & $0.201(630)$ & $0.025(3111)$ & 50 & $96 \pm 9$ & 12 & $12.7 \pm 0.2$ & 1.3 & 30 \\
\hline BAI30 & 1030 & & & & & & & & $13.2 \pm 0.1$ & 1.1 & 100 \\
\hline BAI32 & 640 & 14 & $0.173(273)$ & $0.377(297)$ & $0.025(3111)$ & 99 & $130 \pm 14$ & 6 & $13.5 \pm 0.2$ & 1.2 & 30 \\
\hline
\end{tabular}

Notations: $\rho_{\mathrm{s}}=$ spontaneous track density; $\rho_{\mathrm{i}}=$ induced track density (includes 0.5 geometry factor); $\rho_{\mathrm{d}}=$ density of tracks in the glass dosimeter; $N_{\mathrm{s}}, N_{\mathrm{i}}, N_{\mathrm{d}}=$ number of tracks actually counted to determine the reported track densities. All ages are reported as central ages (Galbraith \& Laslett 1993); calculated with $\zeta=113.6 \pm 3.8$ for glass dosimeter CN2 $\left(\rho_{\mathrm{d}}=2.690 \times 10^{6} \mathrm{~cm}^{-2}\right)$ and $\zeta=11493 \pm 522$ for NBS963 $\left(\rho_{\mathrm{d}}=0.025 \times 10^{6} \mathrm{~cm}^{-2}\right) . P\left(\chi^{2}\right)=$ Chi-squared probability that the single grain ages represent one population; $D=$ age dispersion. If $P\left(\chi^{2}\right)<5$ and/or $D>15$ the single grain ages represent more than one population.

fault scarp, which yielded low-quality (strongly corroded and cloudy) apatites. Most samples have AFT ages between 140 and $100 \mathrm{Ma}$, with relatively high mean track lengths $(c .13 .2 \mu \mathrm{m})$ and narrow $(\sigma<1.1 \mu \mathrm{m})$ negatively skewed track length distributions (Fig. 4).

There is no systematic geographical variation of AFT ages although, with the exception of samples from the Primorsky fault scarp, ages to the SE of the rift seem somewhat younger than those to the NW (Fig. 2). A clear variation of $\mathrm{FT}$ ages and track lengths with elevation does not exist (Fig. 5). Samples from the Priolkhon area (Olkhon block) and the Khamar Daban mountains display nearly vertical age/elevation profiles, with track lengths around $13.0-13.5 \mu \mathrm{m}$. Samples from the Primorsky range (mainly the Primorsky fault scarp) show a very large scatter, the only observable trend being an unusual decrease of $\mathrm{AFT}$ age with elevation. Here, nearly all mean track lengths are shorter than $13 \mu \mathrm{m}$. On a plot of mean track lengths against AFT age, however, the data define two clearly distinguished groups (Fig. 6). Most samples fall in a trend of decreasing track lengths from $140 \mathrm{Ma}(c .13 .7 \mu \mathrm{m})$ down to $100 \mathrm{Ma}$ (c. $12.6 \mu \mathrm{m})$, with four samples defining a separate trend from $160 \mathrm{Ma}(c .12 \mu \mathrm{m})$ up to $230 \mathrm{Ma}(13.8 \mu \mathrm{m})$.

\section{Interpretation}

The large mean track lengths, narrow track length distributions, vertical age/elevation profiles and clear grouping into two AFT age/track length groups suggest that a rapid cooling event occurred around 140-120 Ma. Samples which record ages $>150 \mathrm{Ma}$ would have cooled from temperatures within the apatite partial annealing zone (c. $70-120^{\circ} \mathrm{C}$ ) during this event; samples with ages $<140 \mathrm{Ma}$ from temperatures $>120^{\circ} \mathrm{C}$ (compare Figs 3 and 6). As most track length distributions are relatively long (mean track lengths only $1-1.5 \mu \mathrm{m}$ shorter than those recorded in undisturbed volcanics; Gleadow et al. 1986) and narrow, it is suggested that most samples cooled rapidly, reaching temperatures $<70^{\circ} \mathrm{C}$ at around $120-100 \mathrm{Ma}$. Samples from the Primorsky fault scarp, some of which record ages significantly younger than $100 \mathrm{Ma}$, are considered less reliable; their cloudy and corroded appearance suggests they could have been influenced by (fault related?) fluid leaching. 


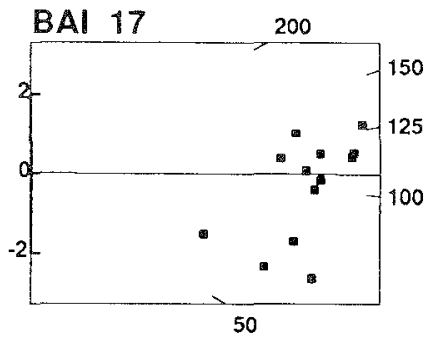

BAI 6

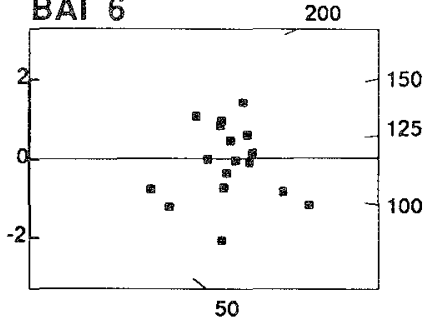

BAI 7

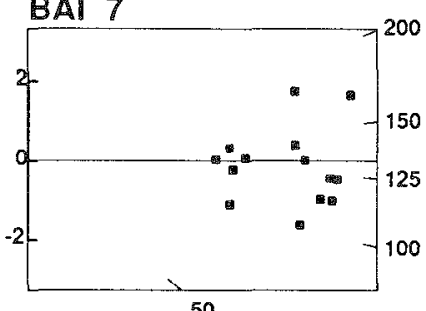

BAl 16
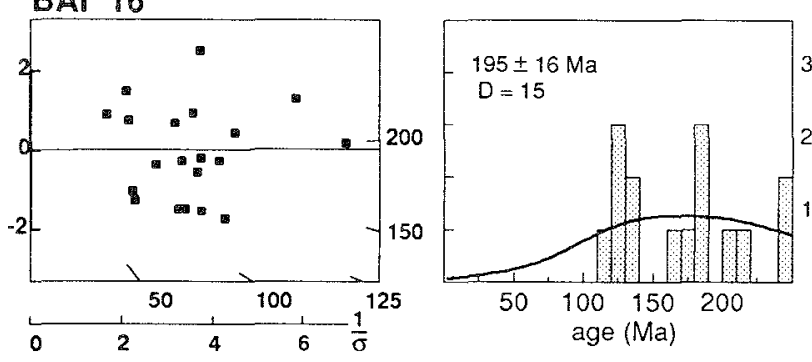
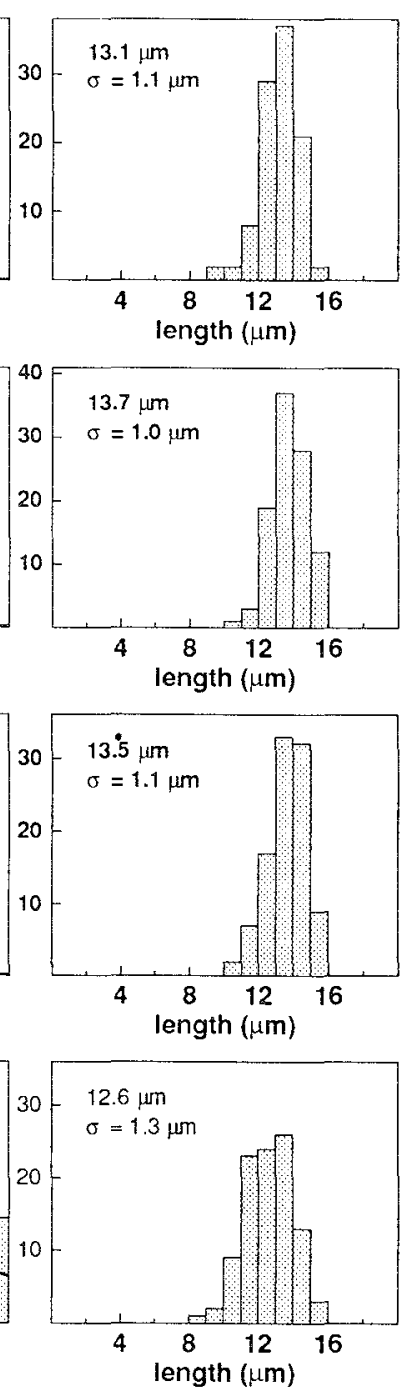

Fig. 4. Representative samples of respectively young (BAI 17), intermediate (BAI 6,7) and old (BAI 16) AFT age. Single-grain age distributions are plotted in a radial plot (left) and as age histograms and probability curves (centre). Radial plots show the precision of individual track counts on the $x$-axis and their standard error on the $y$-axis (cf. Galbraith 1990). Histograms of confined track length distributions are shown on the right.
The samples with oldest AFT ages (BAI16 and 22) record Triassic cooling (around 230-195 Ma). This first cooling phase could have brought these rocks to temperatures around $70^{\circ} \mathrm{C}$, from which they cooled during the second event. The old age and high mean track length for sample BAI22, however, also partly results from the probably high $\mathrm{Cl}$-content of this sample, as indicated by very wide etch pits.

In order to asses the exhumation history of the area more quantitatively, we have inverted the track length distributions from a number of representative samples. The inversion is based on the notion that each track that is formed will experience a different portion of the thermal history of the host rock and will, therefore, exhibit a different degree of annealing (shortening). Thus, a certain thermal history can be related quantitatively to a track length distribution, using a mathematical description of the annealing process. The algorithm used (van der Beek 1995) generates random thermal histories which pass through user-defined $T-t$ regions and calculates fission track age and length distributions from these histories. The set of thermal histories that yield ages and length distributions statistically indistinguishable from those observed define a $T-t$ spectrum which delimits the cooling trajectory of the sample (cf. Lutz \& Omar 1991).

The thermal histories obtained from inversion of track length distributions are shown in Fig. 7. We have used the annealing model of Crowley et al. (1991) for fluor-apatites in the inversion. Since chemical composition data for the analysed apatites are not available, we cannot justify the choice of any particular annealing model. However, the use of different models should not introduce large differences in the thermal histories obtained (cf. van der Beek 1995). The results are consistent with the qualitative interpretation of the data given above. Rapid cooling from temperatures $>120^{\circ} \mathrm{C}$ at around $140 \mathrm{Ma}$ to $c .70^{\circ} \mathrm{C}$ at around $120 \mathrm{Ma}$ is a feature displayed by practically all samples (e.g., BAI $6,7,17$ ). Some samples (BAI 16,17) may have remained at temperatures of around $60-70^{\circ} \mathrm{C}$ for somewhat longer times, cooling down to surface temperatures only during the Late Cretaceous-Palaeogene. BAI 16 even shows a slight heating during the time span 140-120 Ma. As this sample was taken from the border of the Siberian platform sediments, this could indicate burial by overthrusting. However, the kinetics of annealing are not well constrained at temperatures $<60-70{ }^{\circ} \mathrm{C}$ (Corrigan 1993; Ravenhurst et 

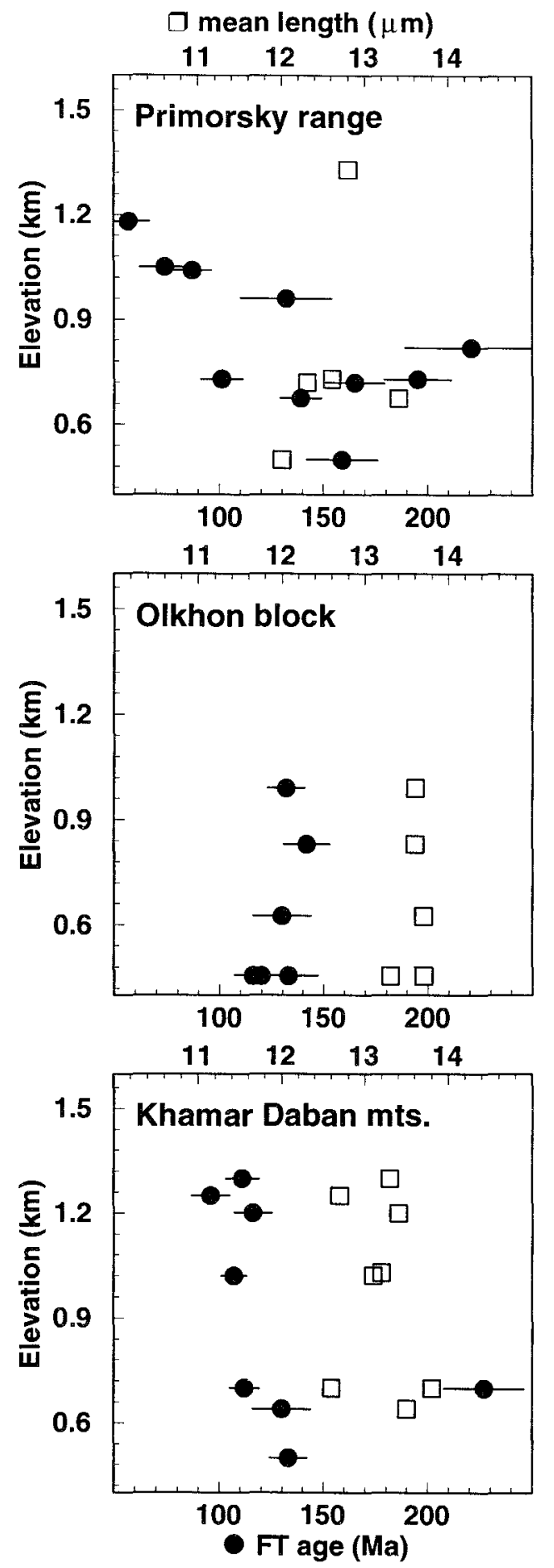

Fig. 5. Age/elevation plots for samples from the Primorsky range, the Olkhon block (both west of Lake Baikal) and the Khamar-Daban mountains (east).

al. 1994) so that the predictions of annealing models should not be overemphasised for this temperature range.

\section{Discussion and conclusions}

The AFT data presented above suggest a rapid phase of cooling during the Early Cretaceous, contemporaneous with the final closure of the Mongol-Okhotsk ocean and collision

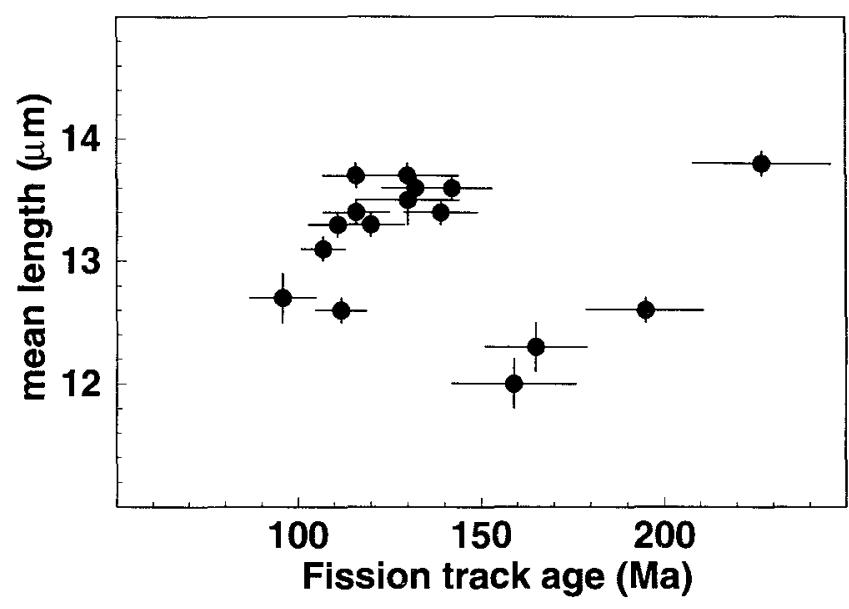

Fig. 6. Plot of mean track length against fission track age for the Baikal rift samples.

of the Siberian and North Chinese cratons. The K-Ar data of Sklyarov et al. (1994) for the metamorphic core complexes to the SE of Lake Baikal also suggest final cooling in the Early Cretaceous. The area to the southeast of Lake Baikal was affected by magmatic activity during this time, as recorded by trachy-basalt flows and mafic dykes with radiometric ages of $127-100 \mathrm{Ma}$ (Ermikov 1994). Jurassic coal-bearing continental deposits, occurring in the basins in this area (Fig. 2), have been affected by contact metamorphism around the dyke intrusions. Thus, the more or less random variation of AFT ages throughout the study area could be, at least partly, a result of different geothermal structure and activity throughout the area. However, differential denudation as a result of vertical block movements probably also played a role. The fact that nearly all samples record $>50^{\circ} \mathrm{C}$ cooling between $140-120 \mathrm{Ma}$ is a

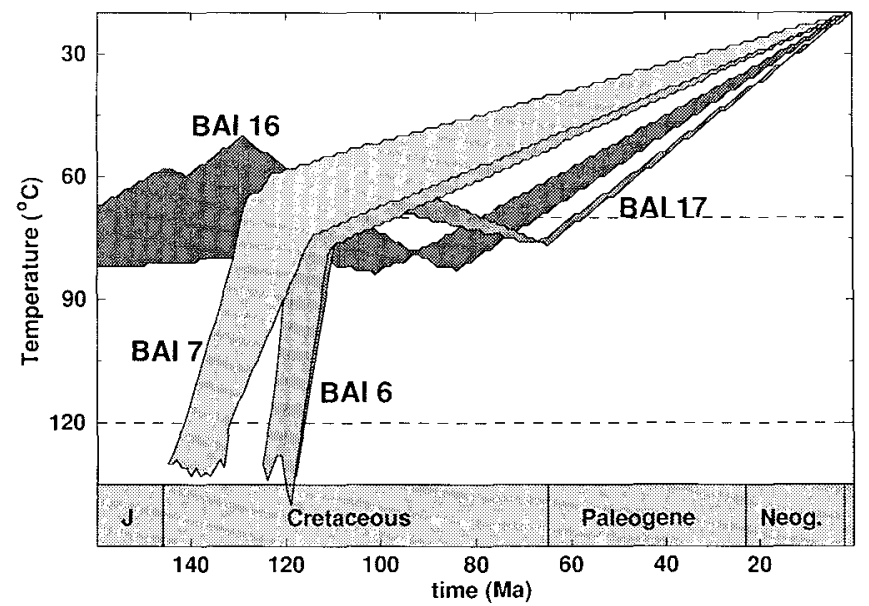

Fig. 7. Model thermal histories obtained from inverting the observed horizontal confined track length distributions (cf. van der Beek 1995) using the annealing model of Crowley et al. (1991) for fluor-apatites. Thermal histories within the shaded bands fit the observed AFT ages within $1 \sigma$ error and pass the KolmogorovSmirnov test for track length distributions at the $95 \%$ confidence level (cf. Lutz \& Omar 1991). Dashed lines at 70 and $120^{\circ} \mathrm{C}$ delimit partial annealing zone and serve as a guide to the eye. 
strong indication for regional denudation during this time. The amount of denudation is difficult to estimate because geothermal gradients for the Mesozoic are unknown, and were probably variable. However, the age/length plot (Fig. 6) suggests that samples with ages around $100 \mathrm{Ma}$ and track lengths $<13 \mu \mathrm{m}$ (e.g., BAI17, BAI27) cooled from temperatures significantly above $120^{\circ} \mathrm{C}$ (possibly around $\left.150^{\circ} \mathrm{C}\right)$. Even when taking very high values for the geothermal gradient $\left(40-50^{\circ} \mathrm{C} \mathrm{km}^{-1}\right)$ into account, this leads to a minimum denudation estimate of $2-3 \mathrm{~km}$. As a comparison, Parfenov et al. (1995) estimate syn-orogenic erosion in the Verkhoyansk fold belt, which was overthrust onto the NE border of the Siberian craton during the Early Cretaceous, to amount to $1.5-2.1 \mathrm{~km}$ from vitrinite reflectance studies.

Mesozoic denudation of the Baikal region is also documented by the widespread occurrence of a planation surface with remains of a palaeosol. The age of this planation surface is generally described as Late CretaceousPalaeocene, and its origin as resulting from post-orogenic peneplanation (e.g., Mats 1993; Kashik \& Mazilov 1994). The fission track data presented here suggest that the onset of exhumation took place already during the Early Cretaceous, i.e. syn-orogenic. The elevation of the Cretaceous-Palaeogene planation surface, which is widely encountered around Lake Baikal, has been used as a pre-rift reference surface (Logatchev 1993; Mats 1993). The AFT data indicate that very little erosional denudation has affected the flanks adjacent to the central Baikal rift since the onset of rifting.

Fieldwork in the Baikal region was conducted within the framework of the CASIMIR project, co-ordinated by J. Klerkx (Royal Museum for Central Africa, Tervuren) and N.A. Logatchev (Institute of the Earth's Crust, Irkutsk, Russia). Support in the field was provided by S. Kuzmin, V. Sankov, R. Moeys and G. Stapel. L. IJlst and T. Vogel-Eissens assisted in sample preparation and processing. Irradiations were carried out at the Dutch Energy Research Centre (ECN) in Petten. We thank B. Windley, M. Zentilli and an anonymous Geological Society internal reader for constructive reviews. Netherlands Research School of Sedimentary Geology Publication no. 960103. Correspondence to P. A. van der Beek (e-mail: peter@rses.anu.edu.au)

\section{References}

Allen, M.B., Windley, B.F., Zhang, C., Zhao, Z.-Y. \& Wang, G.-R. 1991. Basin evolution within and adjacent to the Tien Shan Range, NW China. Journal of the Geological Society, London, 148, 369-378.

Berzin, N.A. \& Dobretsov, N.I. 1994. Geodynamic evolution of Southern Siberia in Late Precambrian-Early Palaeozoic time. In: Coleman, R.G (ed.) Reconstruction of the Paleo-Asian Ocean. VSP International Science Publishers, the Netherlands, 45-62.

Brown, R.W., Summerfield, M.A. \& Glfadow, A.J.W. 1994. Apatite fission-track analysis: Its potential for the estimation of denudation rates and implications for models of long-term landscape development. In: Kirkby, M.J. (ed.) Process Models and Theoretical Geomorphology. Wiley, New York, 24-53.

Corrigan, J. 1993. Apatite fission-track analysis of Oligocene strata in South Texas, U.S.A.: Testing annealing models. Chemical Geology (Isotope Geoscience Section ), 104, 227-249.

Crowley, K.D., Cameron, M. \& Schaffer, R.L. 1991. Experimental studies of annealing of etched fission tracks in fluorapatite. Geochimica ot Cosmochimica Acta, 55, 1449-1465.

Delvaux, D., Moeys, R., Stapei, G., Melnikov, A. \& Ermikov, V. 1995. Paleostress reconstructions and geodynamics of the Baikal region. Central Asia. Part I: Paleozoic and Mesozoic pre-rift evolution. Tectonophysics, $\mathbf{2 5 2}$, in press.

Enkin, R.J., YAnc, Z., Chen, Y. \& Courtillot, V. 1992. Paleomagnetic contraints on the geodynamic history of the major blocks of China from the Permian to the Present. Journal of Geophysical Research, 97, $13953-13989$.

ERMikov, V.D. 1994. Mesozoic precursors of rift structures in Central Asia. Bulletin du Centre de Recherches d'Exploration-Production Elf Aquitaine, 18, 123-134.

Foster, D.A. \& GLEADOW. A.J.W. 1992. The morphotectonic evolution of rift-margin mountains in central Kenya: Constraints from apatite fission-track thermochronology. Earth and Planetary Science Letiers, 113, $157-171$.

Galbratth, R.F. 1990. The radial plot: Graphical assessment of spread in ages. Nuclear Tracks and Radiation Measurements, 17, 207-214

\& LASLETT, G.M. 1993. Statistical models for mixed fission track ages. Nuclear Tracks and Radiation Measurements, 21, 459-470.

Gleadow, A.J.W. \& FitzGerald, P.G. 1987. Uplift history and structure of the Transantarctic Mountains: new evidence from fission track dating of basement apatites in the Dry Valleys area, southern Victoria Land. Earth and Planetary Science Letters, 82, 1-14.

—- Duddy, I.R., Green, P.F. \& Lovering, J.F. 1986. Confined fission track lengths in apatite: a diagnostic tool for thermal history analysis. Contributions to Mineralogy and Petrology, 94, 405-415.

Green, P.F., Dudoy, I.R., Gleadow, A.J.W. \& Lovering, J.F. $1989 a$. Apatite fission-track analysis as a paleotemperature indicator for hydrocarbon exploration. In: NAESER, N.D. \& MCCulloH, T.H. (eds) Thermal history of sedimentary basins. Springer-Verlag, New York. 181-195.

- Laslett, G.M., Hegarty, K.A. Gleadow, A.J.W. \& Lovering, J.F. 1989b. Thermal annealing of fission tracks in apatite 4. Quantitative modelling techniques and extension to geological timescales. Chemical Geology (Isotope Geoscience Section), 79, 155-182.

Hendrix, M.S., Dumitrd, T.A. \& Graham, S.A. 1994. Late Oligocene-early Miocene unroofing in the Chinese Tien Shan: An early effect of the India--Asia collision. Geology, 22, 487-490.

HurFord, A.J. 1990. International union of geological sciences subcommission on geochronology recommendation for the standardization of fission track dating calibration and data reporting. Nuclear Tracks and Radiation Measurements, $\mathbf{1 7}, 233-236$.

— \& GReEN, P.F. 1983. The zeta age calibration of fission-track dating. Chemical Geology (Isotope Geoscience Section), 1, 285-317.

KashiK, S.A. \& MAZILov, V.N. 1994. Main stages and palaeogeography of Cenozoic sedimentation in the Baikal rift system (eastern Siberia). Bulletin du Centre de Recherches d'Exploration-Production Elf Aquitaine, 18, 453-462.

Laslett, G.M., GrFen, P.F., Duddy, I.R. \& Gleadow, A.J.W. 1987. Thermal annealing of fission tracks in apatite 2. A quantitative analysis. Chemical Geology (Isotope Geoscience Seciton), 65, 1-13.

LOGATCHEV, N.A. 1993. History and geodynamics of the Baikal Rift (East Siberia): A review. Bulletin du Centre de Recherches d'ExplorationProduction Elf Aquitaine, 17, 353-370.

_- \& ZoRIN, YU. A. 1992. Baikal rift zone: structure and geodynamics. Tectonophysics, 208, 273-286.

LUTZ, T.M. \& OMAR, G.I. 1991. An inverse method of modeling thermal histories from apatite fission track data. Earth and Planetary Science Letters, 104, 181-195.

Mats, V.D. 1993. The structure and development of the Baikal rift depression. Earth Science Reviews, 34, 81-118.

Mflnikov, A.I., Mazubakov, A.M., Sklyarov, E.V. \& Vasil.jev, E.P. 1994. Baikal rift basement: structure and tectonic evolution. Bulletin du Centre de Recherches d'Exploration-Production Elf Aquitaine, 18, 99-122.

OMAR, G.I. STECKIER, M.S., Buck, W.R. \& KOHN, B.P. 1989. Fission-track analysis of basement apatites at the western margin of the Gulf of Suez rift, Egypt: evidence for synchroneity of uplift and subsidence. Earth and Planetary Science Letters, 94, 316-328.

Parfenov, L.M., Prokopiev, A.V. \& Gaidik, V.V. 1995. Cretaceous frontal thrusts of the Verkhoyansk fold belt, eastern Siberia. Tectonics, 14, $342-358$.

Ravenhust, C.E., Willfitt. S.D., Donelick, R.A. \& Beaumont, C. 1994. Apatite fission track thermochronometry from central Alberta: Implications for the thermal history of the Western Canada Sedimentary Basin. Joumal of Geophysical Research, 99, 20023-20041.

Scotese, C.R. \& Golonka, J. 1992. PAl.EOMAP Paleogeographic Atlas. PALEOMAP progress report 20, Dept. of Geology, University of Texas at Arlington.

Skiyarov, E.V. Belichenko, V.G. Mazubakov, A.M. Melnikov, A.I. \& Donskaya, T.V. 1994. Evolution of the Mongol-Okhotsk ocean and formation of metamorphic core complexes. In: From Paleoasian Ocean to Paleo-Pacific Ocean. Proceedings of an International joint Symposium of IGCP Projects 283, 321, 359, Sapporo, 72-74.

VAN DER BEEK. P.A. 1995. Tectonic Evolution of Continental Rifts-Inferences 
from numerical modelling and fission track thermochronology. PhD Thesis, Vrije Universiteit Amsterdam.

WAGNER, G.A. 1979. Correction and interpretation of fission track ages. In: JÄGER, E. \& HunZiker, J.C. (eds) Lectures in lsotope Geology. Springer
Verlag, Berlin, 170-177.

ZONEnShain, L.P., KuZMin, M.I. \& NaTAPOV, L.M. 1990. Geology of the USSR: A Plate-Tectonic Synthesis. American Geophysical Union Geodynamics Series, 21.

Received 18 September 1995; revised typescript accepted 8 February 1996. Scientific editing by Jane Evans. 